\title{
GRANULOCYTE COLONY-STIMULATING FACTOR (G-CSF) UPREGULATES $\beta 1$ INTEGRIN AND INCREASES MIGRATION OF HUMAN TROPHOBLAST SWAN 71 CELLS VIA PI3K AND MAPK ACTIVATION
}

\author{
Verónica A. Furmento ${ }^{1}$, Julieta Marino ${ }^{1}$, Viviana C. Blank ${ }^{1}$, María Florencia Cayrol ${ }^{2}$, \\ Graciela A. Cremaschi ${ }^{2}$, Rubén C. Aguilar ${ }^{3}$, and Leonor P. Roguin ${ }^{1, *}$ \\ ${ }^{1}$ Instituto de Química y Fisicoquímica Biológicas (UBA-CONICET), Facultad de Farmacia y \\ Bioquímica, Universidad de Buenos Aires, Junín 956, 1113 Buenos Aires, Argentina \\ ${ }^{2}$ Instituto de Investigaciones Biomédicas, Facultad de Ciencias Médicas, Pontificia Universidad \\ Católica Argentina (UCA), CONICET, Alicia M. de Justo 1600, Buenos Aires, Argentina. \\ ${ }^{3}$ Department of Biological Sciences, Purdue University, 201 S. University Street, West Lafayette, \\ IN 47907 USA.
}

\section{Abstract}

\begin{abstract}
Multiple cytokines and growth factors expressed at the fetal-maternal interface are involved in the regulation of trophoblast functions and placental growth, but the role of G-CSF has not been completely established. Based on our previous study showing that G-CSF increases the activity of matrix metalloproteinase-2 and the release of vascular endothelial growth factor in Swan 71 human trophoblast cells, in this work we explore the possible contribution of G-CSF to cell migration and the G-CSF-triggered signaling pathway. We found that G-CSF induced morphological changes on actin cytoskeleton consistent with a migratory cell phenotype. G-CSF also up-regulated the expression levels of $\beta 1$ integrin and promoted Swan 71 cell migration. By using selective pharmacological inhibitors and dominant negative mutants we showed that PI3K, Erk 1/2 and p38 pathways are required for promoting Swan 71 cell motility. It was also demonstrated that PI3K behaved as an upstream regulator of Erk 1/2 and p38 MAPK. In addition, the increase of $\beta 1$ integrin expression was dependent on PI3K activation. In conclusion, our results indicate that G-CSF stimulates $\beta 1$ integrin expression and Swan 71 cell migration by activating PI3K and MAPK signaling pathways, suggesting that G-CSF should be considered as an additional regulatory factor that contributes to a successful embryo implantation and to the placenta development.
\end{abstract}

\footnotetext{
*Corresponding Author: Dr. Leonor P. Roguin, Instituto de Química y Fisicoquímica Biológicas (UBA- CONICET). Facultad de Farmacia y Bioquímica. Universidad de Buenos Aires. Junín 956 - C1113AAD Buenos Aires - Argentina. Telephone Number: +54 11 49648290 Fax Number: +54 114962 5457. rvroguin@qb.ffyb.uba.ar.

Publisher's Disclaimer: This is a PDF file of an unedited manuscript that has been accepted for publication. As a service to our customers we are providing this early version of the manuscript. The manuscript will undergo copyediting, typesetting, and review of the resulting proof before it is published in its final citable form. Please note that during the production process errors may be discovered which could affect the content, and all legal disclaimers that apply to the journal pertain.

Conflict of interest

The authors declare no potential conflict of interest.
} 


\section{Keywords}

G-CSF; Swan 71 cells; MAPK; PI3K; migration; $\beta 1$ integrin

\section{Introduction}

Granulocyte colony-stimulating factor (G-CSF) is a well-known haematopoietic cytokine that promotes proliferation, differentiation and activation of granulocyte lineage cells through binding to cell surface G-CSF receptor (G-CSFR) [1]. Even though the function of G-CSF on the regulation and mobilization of neutrophils has been extensively studied [2-4], G-CSF-triggered biological actions are not exclusively restricted to haematopoietic tissues. Thus, it has been reported that G-CSF induced the migration of endothelial [5,6], glioma [7] and tumor cells [8-10]. In addition, G-CSF signaling enhances the survival of cardiomyocytes [11] and stimulates neurogenesis [12]. The expression of G-CSFR has also been found in placental tissues and trophoblastic cells [13-18], suggesting a possible role of G-CSF in the regulation of placental function. In this regard, G-CSF administration seems to be a promising therapy in some cases of reproductive failure [19]. Thus, the efficiency of GCSF supplementation in the treatment of unexplained recurrent miscarriage suggested putative actions of G-CSF on trophoblast function and early pregnancy [20]. In spite of these findings, since the identification of the G-CSFR-GCSF axis in placental tissues in the late nineties, the G-CSF signaling pathways triggered in trophoblast cells have been scarcely studied. In order to improve our knowledge on this topic, we recently reported the presence of functional G-CSF receptors that activate different signal transduction pathways, such as Jak/STAT, phosphoinositide 3-kinase (PI3K) and mitogen-activated protein kinases (MAPKs), in trophoblastic cell lines [14-15].

Several cytokines and growth factors leading to the activation of different signaling pathways have been involved in the regulation of a variety of biological actions in trophoblast cells, including proliferation, differentiation, migration and invasion [21-23]. Various signaling proteins and transduction pathways such as focal adhesion kinase, MAPKs, Rho/Rho-associated-kinase, PI3K, Wnt cascade and TGF $\beta$-dependent SMAD factors may participate in the control of these multiple biological responses [21-24]. In particular, Erk 1/2 MAPK activation mediated by different hormones or growth factors such as human chorionic gonadotropin [25], epithelial growth factor [26], insulin-like growth factor-2 [27] or hepatocyte growth factor [28] has been related to the promotion of human trophoblast cell motility, whereas the role of p38 signaling in trophoblast cell migration has not been definitely demonstrated [23]. In addition, it has been reported that PI3K/Akt signaling induced by several growth factors of the fetal-maternal interface effectively increases the migration of trophoblast cells [22, 23, 25, 26, 28].

In a previous work we demonstrated that the activation of PI3K/Akt and Erk 1/2 signaling pathways by G-CSF led to an increase of matrix metalloproteinase-2 (MMP-2) activity and vascular endothelial growth factor (VEGF) secretion in Swan 71 cells [15], a human trophoblast cell line derived from a 7-week normal placenta [29]. Based on these findings and considering that both MMP-2 [30] and VEGF [31] have been recognized as important 
factors for placenta development, we hypothesized that G-CSF could effectively cooperate with the complex network of cytokines and factors that regulates embryo implantation [21, $22,23]$. In order to improve our understanding on G-CSF-mediated biological actions in trophoblast cells, in this work we examine the ability of G-CSF to induce a rearrangement of actin cytoskeleton, modify the expression of $\beta 1$ integrin and stimulate Swan 71 cell migration. The contribution of p38, Erk 1/2 and PI3K pathways on G-CSF-induced cell migration was further studied.

\section{Materials and methods}

\subsection{Materials}

Recombinant human G-CSF was supplied by BIO SIDUS S.A., Buenos Aires, Argentina. Mouse monoclonal antibody against $\beta 1$ integrin was from BD Biosciences, NJ, USA. Rabbit polyclonal anti-p38, anti-phospho-p38 (Thr180/Tyr182), secondary anti-rabbit and antimouse IgG horseradish peroxidase antibodies and the PI3K inhibitor Ly294002 were from Santa Cruz Biotechnology, CA, USA. Rabbit polyclonal antibodies anti-Erk 1/2, anti-p-Erk 1/2 (Thr202/Tyr204), anti-Akt, anti-p-Akt (Ser473), anti-p70 S6 Kinase and anti-p-p70 S6 Kinase (Thr421/Ser424) were obtained from Cell Signaling Technology (Beverly, MA, USA). MEK-1 inhibitor PD98059 was from Promega, WI, USA, and p38-MAP kinase inhibitor SB203580 was from Sigma-Aldrich, MO, USA. Dominant negative p38MAPK (DNp38) was a gift from Dr. Roger Davis (University of Massachusetts Medical School, Worcester, MA, USA). The dominant negative mutant of the PI3K regulatory subunit $\mathrm{p} 85$ (DNp85) was provided by Dr. William Hahn (Harvard Medical School, Boston, MA, USA), and dominant negative constructs of ERK1 (pCEP4-ERK1-K71R) and ERK2 (pCEP4ERK2-K52R) were supplied by Dr. Melanie Cobb (University of Texas Southwest Medical Center, Dallas, TX).

\subsection{Cell line and culture conditions}

The human trophoblast cell line, Swan 71, derived by telomerase-mediated transformation of a 7-week cytotrophoblast isolate was kindly provided by Dr. Gil Mor (Department of Obstetrics, Gynecology and Reproductive Sciences, School of Medicine, Yale University, New Haven, USA) [29]. Swan 71 cells were maintained in Dulbecco's Modified Eagle Medium: Nutrient Mixture F-12 (DMEM/F-12) Media (Gibco®, Life Technologies ${ }^{\mathrm{TM}}$, Argentina) supplemented with $10 \%$ FBS, $1 \mathrm{mM}$ sodium pyruvate, $2 \mathrm{mM}$ L-glutamine, 50 $\mathrm{U} / \mathrm{ml}$ penicillin and $50 \mu \mathrm{g} / \mathrm{ml}$ streptomycin.

\subsection{Immunocytochemistry of actin cytoskeleton}

Swan 71 cells grown up on coverslips were incubated $30 \mathrm{~min}$ or $9 \mathrm{~h}$ in the presence or absence of $100 \mathrm{ng} / \mathrm{ml}$ of G-CSF. After washing with saline phosphate buffer (PBS), cells were fixed for $5 \mathrm{~min}$ at room temperature with $4 \%$ p-formaldehyde, and then incubated with rhodamine-phalloidin (Invitrogen, CA, USA) in complete media containing $0.1 \%$ saponin for $60 \mathrm{~min}$ at room temperature. Coverslips were then washed and mounted on slides using Aqua-PolyMount (Polysciences). Stained cells were examined with a Zeiss Axiovert-200M fluorescence microscope. 


\subsection{Transfection}

Cells were transiently transfected with DNp38 (Addgene plasmid 20352), DNp85 (Addgene plasmid 10888), DNErk1/2 or the corresponding control vectors using SuperFect transfection reagent according to the manufacturer's protocols (Qiagen, Germantown, MD, USA). After incubation in the presence or absence of G-CSF, cells were employed for Western blot and wound healing migration assays.

\subsection{Western blot assays}

$\beta 1$ integrin expression levels-non-confluent monolayers of Swan 71 cells maintained $24 \mathrm{~h}$ in serum-free medium were incubated for 4 and $8 \mathrm{~h}$ in the absence or presence of 100 $\mathrm{ng} / \mathrm{ml}$ of G-CSF. Cells were detached using cell scraper, washed with cold PBS and lysed for $30 \mathrm{~min}$ at $4^{\circ} \mathrm{C}$ in $10 \mu \mathrm{l}$ of cold lysis buffer $(1.5 \%$ Triton $\mathrm{X}-100,50 \mathrm{mM} \mathrm{NaCl}, 0.5 \%$ sodium cholate, $0.2 \%$ SDS, $2 \%$ Nonidet P-40, $1 \mu \mathrm{g} / \mathrm{ml}$ leupeptin, $1 \mu \mathrm{g} / \mathrm{ml}$ aprotinin, $1 \mu \mathrm{g} / \mathrm{ml}$ trypsin inhibitor, $1 \mathrm{mM} \mathrm{Na}_{3} \mathrm{VO}_{4}, 1 \mathrm{mM}$ PMSF, $25 \mathrm{mM}$ Tris-HCl, $\mathrm{pH}$ 7.5). Lysates were cleared by centrifugation for $10 \mathrm{~min}$ at $17,000 \times \mathrm{g}$, and the supernatants diluted with sample buffer (40 $\mu \mathrm{g}$ of protein) were submitted to $8 \%$ SDS-PAGE, and then transferred onto PVDF membranes. After blocking non-specific binding sites, membranes were incubated overnight at $4{ }^{\circ} \mathrm{C}$ with an antibody anti- $\beta$ 1integrin. After washing, membranes were incubated for $1 \mathrm{~h}$ at room temperature with anti-mouse $\operatorname{IgG}$ (horseradish peroxidase-conjugated goat IgG) diluted in $10 \mathrm{mM}$ Tris, $130 \mathrm{mM} \mathrm{NaCl}, 0.05 \%$ Tween-20, pH 7.4, containing 1\% BSA. Immunoreactive proteins were visualized using the Pierce ${ }^{\circledR}$ ECL Plus Western blotting substrate (Thermo Scientific, Rockford, IL, USA) according to the manufacturer's instructions. For quantification of band intensity, Western blots were scanned using a densitometer (Gel Pro Analyzer 4.0).

MAPK activation-to measure p38 and JNK phosphorylation, monolayers of Swan 71 cells maintained $24 \mathrm{~h}$ in serum-free medium were treated with or without $100 \mathrm{ng} / \mathrm{ml}$ of GCSF for different times. Cells were then solubilized for $30 \mathrm{~min}$ at $4^{\circ} \mathrm{C}$ in $10 \mu \mathrm{l}$ of lysis buffer (0.5\% Triton X-100, $1 \mu \mathrm{g} / \mathrm{ml}$ leupeptin, $1 \mu \mathrm{g} / \mathrm{ml}$ aprotinin, $1 \mu \mathrm{g} / \mathrm{ml}$ trypsin inhibitor, $10 \mathrm{mM}$ $\mathrm{Na}_{4} \mathrm{P}_{2} \mathrm{O}_{7}, 10 \mathrm{mM} \mathrm{NaF}, 150 \mathrm{mM} \mathrm{NaCl}, 1 \mathrm{mM} \mathrm{Na}_{3} \mathrm{VO}_{4}, 1 \mathrm{mM}$ PMSF, $1 \mathrm{mM}$ EDTA, $50 \mathrm{mM}$ Tris, $\mathrm{pH}$ 7.4), and $40 \mu \mathrm{g}$ of proteins were submitted to 10\% SDS-PAGE, followed by transfer onto PVDF membranes. After blocking non-specific binding sites, membranes were treated as described previously.

\subsection{Flow cytometry assays}

After $24 \mathrm{~h}$ of incubation in serum-free culture medium, Swan 71 cells were incubated for different times in the presence or absence of $100 \mathrm{ng} / \mathrm{ml}$ of G-CSF. After harvesting and washing with PBS, $1 \times 10^{6}$ cells were fixed in $1 \%$ p-formaldehyde and permeabilized with $0.1 \%$ Tween-PBS for 20 minutes. Cells were then labelled with anti- $\beta 1$ integrin antibody for $1 \mathrm{~h}$ and then with the corresponding anti- FITC conjugated secondary antibody. Data were acquired using a BD Accuri TM C6 flow cytometer (BD Biosciences, CA, USA), analyzed using the BD Accuri C6 software and expressed as the percentage of positive cells relative to the total cell number (20,000 events) evaluated. 


\subsection{Cell migration assays}

Transwell cell migration assays-Swan 71 cells trypsinized and resuspended in complete culture medium were applied on 8- $\mu \mathrm{m}$ pore transwell inserts (Corning Inc.) coated with $10 \mu \mathrm{g} / \mathrm{ml}$ fibronectin on the upper and bottom side of the insert membrane. After $4 \mathrm{~h}$, inserts were first incubated overnight in wells containing medium with $0.1 \% \mathrm{FBS}$, and then in wells containing serum-free medium in the upper chamber and serum-free medium with or without $100 \mathrm{ng} / \mathrm{ml}$ of G-CSF in the lower chamber. In addition, medium containing $10 \%$ FBS in the lower chamber was used as positive control. Cells were allowed to migrate for 9 $\mathrm{h}$ before fixation in $4 \% \mathrm{p}$-formaldehyde. Cells on fixed membranes were stained with DAPI and visualized by epifluorescence microscopy. Total nuclei were counted per membrane in order to obtain cell inputs, and then the upper side of the membrane was swabbed with a Qtip and rinsed with PBS. Cells on the bottom side of the membrane were visualized and scored as migrants if their nuclei passed through the membrane pores.

"Wound-healing" migration assay-Swan 71 cells were plated on 96-well dishes and grown to $90 \%$ confluence in $100 \mu \mathrm{l}$ of complete culture medium. After $24 \mathrm{~h}$ of incubation in serum-deprived culture medium, cell monolayers were scratched using a p10 pipette tip and then treated with $100 \mathrm{ng} / \mathrm{ml}$ of G-CSF. Cells were allowed to migrate for $16 \mathrm{~h}$ and photographs were taken with an inverted microscope at 0 and $16 \mathrm{~h}$. In some experiments, cells were transfected with DNp38, DNp85 or DNErk 1/2 or with the corresponding empty vector, as described previously. In other experiments, cells were pre-incubated for $1 \mathrm{~h}$ with 2 $\mu \mathrm{M}$ SB203580 (SB), 1 MM Ly294002 (Ly) or 1 MM PD98059 (PD). No effect on Swan 71 cell proliferation was observed at these concentrations of inhibitors (data not shown).

\subsection{Statistical analysis}

GraphPad Prism 5.00 software was used for data analysis. Results of normally distributed data represent mean \pm SE. Comparisons were performed using one way analysis of variance (ANOVA) followed by Bonferroni or Tukey post-hoc tests where appropriate. Student's t-test was used when the values of two groups were analyzed. Some part of the biological data analyzed within this work did not follow a normal distribution (failed normality tests). Given their non-parametric nature, data distributions were shown as box plots depicting the median, 25-75 (bottom and top of box, respectively) and 10-90 (whiskers) percentiles. When appropriate, statistical significance was evaluated using the non-parametric Wilcoxon test. Values were considered significantly different when $\mathrm{p}<0.05$.

\section{Results}

\subsection{Effect of G-CSF on actin cytoskeleton organization in Swan 71 cells}

Based on our previous findings showing the ability of G-CSF to increase the expression of MMP-2 and VEGF in Swan 71 cells [15], we inquired whether the cytokine would contribute to trophoblast cell migration and consequently embryo implantation by promoting cell motility. Since actin cytoskeleton rearrangement is required for cell migration [32,33], we examined actin morphology after rhodamine-phalloidin staining of Swan 71 cells incubated $30 \mathrm{~min}$ or $9 \mathrm{~h}$ in the presence or absence of $100 \mathrm{ng} / \mathrm{ml}$ of G-CSF. As shown in Fig. 1 , no change in actin organization was observed in cells treated for 30 min with G-CSF, 
whereas a significant increase in the amount of cells with migratory phenotype characterized by the presence of lamellipodium at the leading edge and tail retraction - was detected after $9 \mathrm{~h}$ of G-CSF exposure.

\subsection{G-CSF induces expression of human $\beta 1$ integrin in Swan 71 cells}

The switching in the expression pattern of integrins during placentation characterizes the transition to an invasive phenotype of extravillous trophoblast. In human placenta, the invasive trophoblasts of the first trimester reduce the expression of a $6 \beta 4$ integrin while increase the expression of $\alpha 5 \beta 1, \alpha v \beta 1, \alpha v \beta 3$ and $\alpha 1 \beta 1$ integrins along the invasive pathway [34,35]. Since an increase in $\beta 1$ integrin expression levels occurs when cells shift towards a more invasive phenotype, we decided to examine whether G-CSF regulates the level of $\beta 1$ integrin in Swan 71 cells. After incubating cells with $100 \mathrm{ng} / \mathrm{ml}$ of G-CSF for different times, a significant increase in the population of $\beta 1$-positive cells was observed (Fig. 2A). Thus, the percentage of positive cells for $\beta 1$ integrin varied from $25.8 \%$ to $32.7 \%$ and $36.9 \%$ after $4 \mathrm{~h}$ and $8 \mathrm{~h}$ of incubation, respectively. Similarly, a considerable raise in the expression levels of $\beta 1$ integrin was detected after $4 \mathrm{~h}$ and $8 \mathrm{~h}$ of G-CSF treatment (Fig. 2B). No change was revealed at longer incubations times ( $12 \mathrm{~h}$ and $16 \mathrm{~h}$, data not shown).

\subsection{G-CSF promotes migration of Swan 71 cells}

The ability of G-CSF to induce Swan 71 cell migration was next studied using both Transwell and wound healing assays. After applying cells on Transwell chambers, cells were incubated $9 \mathrm{~h}$ in serum-free medium in the presence or absence of $100 \mathrm{ng} / \mathrm{ml}$ of G-CSF or $10 \%$ FBS as positive control. G-CSF induced an increase of about $15 \%$ in the total amount of migrated cells, whereas an enhancement of $35 \%$ was obtained when cells were incubated in the presence of serum (Fig. 3A). In addition, after performing an scrape in a monolayer of Swan 71 cells, G-CSF (100 ng/ml) induced cell migration (wound closure $~ 15 \%)$ after $16 \mathrm{~h}$ of incubation in serum-free medium, while a more substantial closure ( $60 \%)$ was obtained in the presence of serum (Fig. 3B). It should be mentioned that G-CSF treatment have no effect on Swan 71 cell proliferation under any of the experimental conditions herein employed, as previously reported [15].

\subsection{MAPK pathways activated by G-CSF in Swan 71 cells}

It has been reported that G-CSF stimulates the activation of MAPK pathways, including Erk $1 / 2$, p38 and JNK pathways in haematopoietic cells [36,37]. The biological outcomes of MAPK activation involve cell proliferation, differentiation, survival, migration and invasion [37]. In a previous work, we demonstrated that G-CSF activates Erk 1/2 MAPK pathway in Swan 71 cells to regulate MMP-2 activity and VEGF secretion [15], but the possible activation of other additional MAPK cascades was not explored. To determine whether p38 or JNK MAPK pathways are also activated by G-CSF in Swan 71 cells, phosphorylation kinetics of phospho-p38 (p-p38) and phospho-JNK 1/2 (p-JNK1, p-JNK2) were determined by Western blot analyses in serum-deprived cells. As shown in Suppl. Fig. 1, levels of p-p38 increased after 30-45 min of stimulation with $100 \mathrm{ng} / \mathrm{ml}$ of G-CSF, whereas no variation was detected in JNK 1/2 phosphorylation of G-CSF-treated cells with respect to cells incubated in the absence of cytokine. Based on these findings, the possible contribution of both $\mathrm{p} 38$ and Erk 1/2 activation in G-CSF-stimulated cell migration was next studied. 


\subsection{Involvement of p38, Erk $1 / 2$ and PI3K on G-CSF-induced migration of Swan 71 cells}

To evaluate the role of MAPKs activation in G-CSF-induced Swan 71 cell migration, we first employed selective pharmacological inhibitors in wound healing migration assays. Since we have previously shown that G-CSF activates PI3K pathway in Swan 71 cells [15], an inhibitor of PI3K was also included. The efficiency of each inhibitor to block the corresponding pathway was determined in previous works [14,15]. As shown in Fig. 4A, pre-treatment of Swan 71 cells with $2 \mu \mathrm{M} \mathrm{SB}, 1 \mu \mathrm{M}$ PD or $1 \mu \mathrm{M}$ Ly effectively reversed the enhancement of cell migration induced by G-CSF. No effect on cell survival was observed at these inhibitor concentrations, indicating that the decrease of cell motility was not attributable to a cytotoxic effect (Suppl. Fig. 2). We then confirmed these results by blocking p38, Erk 1/2 and PI3K pathways with the corresponding dominant-negative mutants: a p38 construct, in which the phosphorylated motifs Thr 180 and Tyr 182 were mutated to Ala and Phe, respectively; Erk 1/2 mutants, in which mutations of Lys 71 (Erk1) and Lys 52 (Erk2) to Arg impair the catalytic efficiency of the kinases; and the p85 delta-iSH2 mutant of the p85 regulatory subunit of PI3K, lacking the binding site for the p110 catalytic subunit. The effectiveness of each construct to inhibit the related pathways was assessed by Western blot assays. Thus, as shown in Suppl. Fig. 3, the corresponding DN mutants significantly reduced p-p38, phospho-p70 S6 kinase (p70S6K phosphorylation at Thr421/Ser424 is dependent on MEK/Erk pathway) [38,39] and phospho-Akt (p-Akt) expression levels in G-CSF-stimulated cells. When wound-healing assays were performed with DN transfected cells, it was demonstrated that G-CSF-induced cell migration was effectively reduced in cells transfected with DNp38, DNErk 1/2 and DNp85 constructs compared to cells transfected with the corresponding control vectors (Fig. 4B). It should be mentioned that, in this case, G-CSF migratory effect on transfected cells was observed after $24 \mathrm{~h}$ instead of $16 \mathrm{~h}$ (see Fig. 3B). Taken together, these results demonstrate that the activation of p38, Erk 1/2 and PI3K pathways is required for promoting Swan 71 cell migration induced by G-CSF.

To elucidate whether PI3K behaves as an upstream regulator of Erk 1/2 and p38 pathways, G-CSF-induced phosphorylation of Erk 1/2 and p38 was examined in Swan 71 cells pretreated with Ly or in cells transfected with the DNp85 mutant. As shown in Fig. 5A and C, the incubation of cells with Ly diminished p-Erk 1/2 and p-p38 levels in G-CSF-stimulated cells. In addition, G-CSF effect on Erk 1/2 and p38 phosphorylation was also reversed in DNp85 transfected cells (Fig. 5B and D), indicating that PI3K is required for both p38 and Erk $1 / 2$ activation. We also examined the participation of PI3K and MAPK signaling in the increase of $\beta 1$ integrin expression levels induced by G-CSF. Results showed in Fig. 6A revealed that pre-incubation of Swan 71 cells with SB, PD or Ly significantly reversed the effect of G-CSF on $\beta 1$ integrin expression. It was subsequently demonstrated that cell transfection with the DNp85 construct completely suppressed the increment of $\beta 1$ integrin (Fig. 6B). Thus, results obtained indicate that the activation of p38, Erk 1/2 and PI3K pathways contribute to regulate the expression levels of $\beta 1$ integrin.

\section{Discussion}

In a previous work we demonstrated that G-CSF increases the activity of MMP-2 and VEGF secretion in Swan 71 cells, a 7-week human trophoblast cell line exhibiting a phenotype

Exp Cell Res. Author manuscript; available in PMC 2017 March 15. 
similar to extravillous trophoblasts [29]. These cells would maintain characteristics of primary trophoblast from the first trimester in contrast to cells derived from choriocarcinoma and some other trophoblast cell lines generated by SV40 transformation. Since extravillous trophoblasts generated from anchoring villi during the first weeks of pregnancy acquire the ability to migrate into stromal areas of the maternal decidua [21-23], we hypothesized that G-CSF, as other growth factors identified in the fetal-maternal interface, might contribute to facilitate cell motility. In this context, we showed that G-CSF induced morphological changes of actin cytoskeleton, increased the expression levels of $\beta 1$ integrin and promoted trophoblast cell migration. Integrins are $\alpha / \beta$ heterodimeric membrane receptors that connect extracellular matrix ligands to the actin cytoskeleton, controlling cytoskeletal remodelling and various cellular responses including migration, differentiation, and proliferation [40, 41]. The up-regulation of the expression levels of $\beta 1$ integrin herein reported is consistent with the change in the integrin profile occurring during trophoblast differentiation. Thus, when cytotrophoblast residing at the villous basement membrane differentiate into extravillous trophoblasts, the expression of a $6 \beta 4$ integrin is suppressed and higher levels of different integrins containing $\beta 1$ subunit are found [34,35]. It has also been reported that the stimulation of trophoblast cell migration/invasion by different cytokines and chemokines might be mainly modulated by an increase in the expression levels of integrins, including $\beta 1$, and MMPs [42, 43]. Based on these findings, we conclude that G-CSF promoted the acquisition of a more migratory/invasive phenotype by increasing the expression of $\beta 1$ integrin. In addition, acting as different cytokines and growth factors that facilitate trophoblast cell migration [23,42-45], we showed that G-CSF promoted cell motility and induced actin cytoskeleton morphological changes, such as lamellipodial protrusions and tail retraction, in accordance with a migratory phenotype [46,47]. Although G-CSF behaves as a potent migratory stimulus for haematopoietic cells [48], just a moderate effect was observed in Swan 71 cells. In this regard, it should be considered that a wide range of G-CSF migratory potencies has been reported in non-haematopoietic tissues, being slight responses (up to 1.4-fold increase) induced in glioma cells [7] and head and neck squamous cell carcinomas [8], and more pronounced effects (up to 6-fold increase) observed in rat oval cells [49] and gastric and colon cancer cells [50]. In spite of the differences observed in the G-CSF-migratory potency, this cytokine might be considered as a promoting factor for cell migration, while other G-CSF-mediated biological effects, such as the proliferative and survival responses, seem to be more restricted to some cell types.

We next examined the signaling pathways involved in G-CSF-induced cell migration and demonstrated that PI3K, Erk 1/2 and p38 pathways are required for promoting Swan 71 motility. Thus, pre-treatment of Swan 71 cells with specific pharmacological inhibitors or dominant negative mutants of the corresponding signal transduction pathways notably blocked the increment of cell migration induced by G-CSF. It was also probed that PI3K behaved as an upstream regulator of Erk 1/2 and p38 MAPK. The involvement of Erk 1/2 [25-28] and PI3K [22,23,25,26,28] pathways in the promotion of trophoblast cell migration induced by various growth factors has been previously reported, but the participation of GCSF had not been assessed. Besides, the influence of $\mathrm{p} 38$ signaling in trophoblast cell migration remained uncertain up to now [23]. Thus, this is the first report showing that GCSF stimulates, through activation of PI3K, Erk 1/2 and p38 cascades, the migration of 
trophoblast cells. In addition, we also found that PI3K mediates the increase of $\beta 1$ integrin expression induced by G-CSF, being the increment of $\beta 1$ integrin completely inhibited both in cells pre-incubated with Ly as well as in cells transfected with the DNp85 construct. Furthermore, after incubating Swan 71 cells in the presence of PD or SB, we next demonstrated that Erk 1/2 and p38 signaling pathways, both downstream PI3K, are also involved in the regulation of $\beta 1$ integrin levels. In this regard, it is interesting to mention that besides the role played by MAPKs after interaction of integrins with extracellular matrix molecules, MAPKs signalling triggered by growth factors also might regulate integrin expression. Thus, the role of Erk as an "inside out" signal leading to the up-regulation of integrin levels and cell migration has been previously reported in human osteoblastic cells [51].

In summary, our results suggest that G-CSF contributes to Swan 71 cell motility and increases the expression level of $\beta 1$ integrin cell receptor through activation of PI3K, Erk 1/2 and p38 signaling pathways. A model illustrating the pathways involved in G-CSF-induced cell motility is showed in Figure 7. Based on our results, we consider that G-CSF should be included within the network of cytokines, hormones and growth factors expressed in the fetal-maternal interface as an additional regulatory factor that plays a role in the processes of embryo implantation and placenta growth.

\title{
Supplementary Material
}

Refer to Web version on PubMed Central for supplementary material.

\section{Acknowledgments}

This work was supported by grants from Consejo Nacional de Investigaciones Científicas y Técnicas (CONICET, PIP 0066), Agencia Nacional de Promoción Científica y Tecnológica (PICT-2012-1328), Universidad de Buenos Aires (UBACYT 20020130100024 and 20020130100289) and National Institute of Health (5 R21 CA151961).

\author{
Abbreviations \\ Erk extracellular signal-regulated kinases \\ FBS fetal bovine serum \\ G-CSF granulocyte colony-stimulating factor \\ MAPKs mitogen-activated protein kinases \\ PI3K phosphatidylinositol 3-kinase \\ PMSF phenylmethanesulfonyl fluoride \\ PVDF polyvinylidene difluoride
}

\section{References}

1. Demetri GD, Griffin JD. Granulocyte colony-stimulating factor and its receptor. Blood. 1991; 78:2791-2808. [PubMed: 1720034] 
2. van de Geijn GJ, Aarts LH, Erkeland SJ, Prasher JM, Touw IP. Granulocyte colony-stimulating factor and its receptor in normal hematopoietic cell development and myeloid disease. Rev. Physiol. Biochem. Pharmacol. 2003; 149:53-71. [PubMed: 12687405]

3. Touw IP, van de Geijn GJ. Granulocyte colony-stimulating factor and its receptor in normal myeloid cell development, leukemia and related blood cell disorders. Front. Biosci. 2007; 12:800-815. [PubMed: 17127321]

4. Liongue C, Wright C, Russell AP, Ward AC. Granulocyte colony-stimulating factor receptor: stimulating granulopoiesis and much more. Int. J. Biochem. Cell. Biol. 2009; 41:2372-2375. [PubMed: 19699815]

5. Bussolino F, Ziche M, Wang JM, Alessi D, Morbidelli L, Cremona O, Bosia A, Marchisio PC, Mantovani A. In vitro and in vivo activation of endothelial cells by colony-stimulating factors. J. Clin. Invest. 1991; 87:986-995. [PubMed: 1705569]

6. Fuste B, Mazzara R, Escolar G, Merino A, Ordinas A, Diaz-Ricart M. Granulocyte colonystimulating factor increases expression of adhesion receptors on endothelial cells through activation of p38 MAPK. Haematologica. 2004; 89:578-585. [PubMed: 15136221]

7. Wang J, Yao L, Zhao S, Zhang X, Yin J, Zhang Y, Chen X, Gao M, Ling EA, Hao A, Li G. Granulocyte-colony stimulating factor promotes proliferation, migration and invasion in glioma cells. Cancer Biol. Ther. 2012; 13:389-400. [PubMed: 22313638]

8. Gutschalk CM, Herold-Mende CC, Fusenig NE, Mueller MM. Granulocyte colony-stimulating factor and granulocyte-macrophage colony-stimulating factor promote malignant growth of cells from head and neck squamous cell carcinomas in vivo. Cancer Res. 2006; 66:8026-8036. [PubMed: 16912178]

9. Park S, Kim ES, Noh DY, Hwang KT, Moon A. H-Ras-specific upregulation of granulocyte colonystimulating factor promotes human breast cell invasion via matrix metalloproteinase-2. Cytokine. 2011; 55:126-133. [PubMed: 21524920]

10. Chakraborty A A, White SM, Lerner SP. Granulocyte colony-stimulating factor receptor signals for beta1-integrin expression and adhesion in bladder cancer. Urology. 2004; 63:177-183. [PubMed: 14751388]

11. Harada M, Qin Y, Takano H, Minamino T, Zou Y, Toko H, Ohtsuka M, Matsuura K, Sano M, Nishi J, Iwanaga K, Akazawa H, Kunieda T, Zhu W, Hasegawa H, Kunisada K, Nagai T, Nakaya H, Yamauchi-Takihara K, Komuro I. G-CSF prevents cardiac remodeling after myocardial infarction by activating the Jak-Stat pathway in cardiomyocytes. Nat. Med. 2005; 11:305-311. [PubMed: 15723072]

12. Jung KH, Chu K, Lee ST, Kim SJ, Sinn DI, Kim SU, Kim M, Roh J,K. Granulocyte colonystimulating factor stimulates neurogenesis via vascular endothelial growth factor with STAT activation. Brain Res. 2006; 1073-1074:190-201. [PubMed: 16423324]

13. Uzumaki H, Okabe T, Sasaki N, Hagiwara K, Takaku F, Tobita M, Yasukawa K, Ito S, Umezawa Y. Identification and characterization of receptors for granulocyte colony-stimulating factor on human placenta and trophoblastic cells. Proc. Natl. Acad. Sci. USA. 1989; 86:9323-9326. [PubMed: 2480598]

14. Marino VJ, Roguin LP. The granulocyte colony stimulating factor (G-CSF) activates Jak/STAT and MAPK pathways in a trophoblastic cell line. J. Cell. Biochem. 2008; 103:1512-1523. [PubMed: 17879956]

15. Furmento VA, Marino J, Blank VC, Roguin LP. The granulocyte colony-stimulating factor (GCSF) upregulates metalloproteinase-2 and VEGF through PI3K/Akt and Erk1/2 activation in human trophoblast Swan 71 cells. Placenta. 2014; 35:937-946. [PubMed: 25249155]

16. Shorter SC, Vince GS, Starkey PM. Production of granulocyte colony-stimulating factor at the materno-foetal interface in human pregnancy. Immunology. 1992; 75:468-474. [PubMed: 1374054]

17. Mc Cracken SA, Grant KE, McKenzie IZ, Redman CWG, Mardon HJ. Gestational regulation of granulocyte-colony stimulating factor receptor expression in the human placenta. Biol. Reproduction. 1999; 60:790-796. 
18. Marino VJ, Sterin-Prync AE, Carbonetto CH, Roguin LP. Conformational and sequential epitopes on the human granulocyte-colony stimulating factor (hG-CSF) and their role in binding to human placenta receptors. Cytokine. 2001; 16:41-50. [PubMed: 11683584]

19. Rahmati M, Petitbarat M, Dubanchet S, Bensussan A, Chaouat G, Ledee N. Granulocyte-Colony Stimulating Factor related pathways tested on an endometrial ex-vivo model. PLoS One. 2014; 9:e102286. [PubMed: 25275446]

20. Scarpellini F, Sbracia M. Use of granulocyte colony-stimulating factor for the treatment of unexplained recurrent miscarriage: a randomised controlled trial. Hum. Reprod. 2009; 24:27032708. [PubMed: 19617208]

21. Pollheimer J, Knöfler M. Signalling pathways regulating the invasive differentiation of human trophoblasts: a review. Placenta. 2005; 26(Suppl A):S21-30. [PubMed: 15837062]

22. Fitzgerald JS, Busch S, Wengenmayer T, Foerster K, de la Motte T, Poehlmann TG, Markert UR. Signal transduction in trophoblast invasion. Chem. Immunol. Allergy. 2005; 88:181-199. [PubMed: 16129946]

23. Knöfler M. Critical growth factors and signalling pathways controlling human trophoblast invasion. Int. J. Dev. Biol. 2010; 54:269-280. [PubMed: 19876833]

24. Knöfler M, Pollheimer J. Human placental trophoblast invasion and differentiation: a particular focus on Wnt signaling. Front. Genet. 2013; 4:190. [PubMed: 24133501]

25. Prast J, Saleh L, Husslein H, Sonderegger S, Helmer H, Knöfler M. Human chorionic gonadotropin stimulates trophoblast invasion through extracellularly regulated kinase and akt signaling. Endocrinology. 2008; 149:979-987. [PubMed: 18063683]

26. Qiu Q, Yang M, Tsang BK, Gruslin A. Both mitogen-activated protein kinase and phosphatidylinositol 3-kinase signalling are required in epidermal growth factor-induced human trophoblast migration. Mol. Hum. Reprod. 2004; 10:677-684. [PubMed: 15235105]

27. McKinnon T, Chakraborty C, Gleeson LM, Chidiac P, Lala PK. Stimulation of human extravillous trophoblast migration by IGF-II is mediated by IGF type 2 receptor involving inhibitory G protein(s) and phosphorylation of MAPK. J. Clin. Endocrinol. Metab. 2001; 86:3665-3674. [PubMed: 11502794]

28. Cartwright JE, Tse WK, Whitley GS. Hepatocyte growth factor induced human trophoblast motility involves phosphatidylinositol-3-kinase, mitogen-activated protein kinase, and inducible nitric oxide synthase. Exp. Cell. Res. 2002; 279:219-226. [PubMed: 12243747]

29. Straszewski-Chavez SL, Abrahams VM, Alvero AB, Aldo PB, Ma Y, Guller S, Romero R, Mor G. The isolation and characterization of a novel telomerase immortalized first trimester trophoblast cell line, Swan 71. Placenta. 2009; 30:939-948. [PubMed: 19766308]

30. Cohen M, Meisser A, Bischof P. Metalloproteinases and human placental invasiveness. Placenta. 2006; 27:783-793. [PubMed: 16249026]

31. Holmes K, Roberts OL, Thomas AM, Cross MJ. Vascular endothelial growth factor receptor-2: Structure, function, intracellular signalling and therapeutic inhibition. Cell. Signal. 2007; 19:20032012. [PubMed: 17658244]

32. Pollard TD, Cooper JA. Actin, a central player in cell shape and movement. Science. 2009; 326:1208-12. [PubMed: 19965462]

33. Leduc C, Etienne-Manneville S. Intermediate filaments in cell migration and invasion: the unusual suspects. Curr. Opin. Cell. Biol. 2015; 32:102-12. [PubMed: 25660489]

34. Damsky CH, Librach C, Lim K-H, Fitzgerald ML, McMaster MT, Janatpour M, Zhou Y, Logan SK, Fisher SJ. Integrin switching regulates normal trophoblast invasion. Development. 1994; 120:3657-66. [PubMed: 7529679]

35. Kaufmann P, Castellucci M. Extravillous trophoblast in the human placenta: a review. Placenta. 1997; 18:21-65.

36. Rausch O, Marshall CJ. Cooperation of p38 and extracellular signal-regulated kinase mitogenactivated protein kinase pathways during granulocyte colony-stimulating factor-induced hemopoietic cell proliferation. J. Biol. Chem. 1999; 274:4096-4105. [PubMed: 9933603]

37. Kendrick TS, Bogoyevitch MA. Activation of mitogen-activated protein kinase pathways by the granulocyte colony-stimulating factor receptor: mechanisms and functional consequence. Front. Biosci. 2007; 12:591-607. [PubMed: 17127320] 
38. Shi Y, Hsu JH, Hu L, Gera J, Lichtenstein A. Signal pathways involved in activation of p70S6K and phosphorylation of 4E-BP1 following exposure of multiple myeloma tumor cells to interleukin-6. J. Biol. Chem. 2002; 277:15712-15720. [PubMed: 11872747]

39. Ahmed M, Kundu GC. Osteopontin selectively regulates p70S6K/mTOR phosphorylation leading to NF-kappaB dependent AP-1-mediated ICAM-1 expression in breast cancer cells. Mol. Cancer. 2010; 9:101. [PubMed: 20459645]

40. Hood JD, Cheresh DA. Role of integrins in cell invasion and migration. Nat. Rev. Cancer. 2002; 2:91-100. [PubMed: 12635172]

41. Simpson MA, Bradley WD, Harburger D, Parsons M, Calderwood DA, Koleske AJ. Direct interactions with the integrin $\beta 1$ cytoplasmic tail activate the Abl2/Arg kinase. J. Biol. Chem. 2015; 290:8360-8372. [PubMed: 25694433]

42. Jovanović M, Stefanoska I, Radojcić L, Vićovac L. Interleukin-8 (CXCL8) stimulates trophoblast cell migration and invasion by increasing levels of matrix metalloproteinase (MMP)2 and MMP9 and integrins alpha5 and beta1. Reproduction. 2010; 139:789-798. [PubMed: 20133364]

43. Li CM, Hou L, Zhang H, Zhang WY. CCL17 Induces Trophoblast Migration and Invasion by Regulating Matrix Metalloproteinase and Integrin Expression in Human First-Trimester Placenta. Reprod. Sci. 2014:1933719113519170. Epub ahead of print. [PubMed: 24401476]

44. Han J J, Li L, Hu J, Yu L, Zheng Y, Guo J, Zheng X, Yi P, Zhou Y. Epidermal growth factor stimulates human trophoblast cell migration through Rho A and Rho C activation. Endocrinology. 2010; 151:1732-1742. [PubMed: 20150581]

45. Zhou Y, Yuge A, Rajah AM, Unek G, Rinaudo PF, Maltepe, E E. LIMK1 regulates human trophoblast invasion/differentiation and is down-regulated in preeclampsia. Am. J. Pathol. 2014; 184:3321-3331. [PubMed: 25307528]

46. Rottner K, Stradal TE. Actin dynamics and turnover in cell motility, Running with neighbors: coordinating cell migration and cell-cell adhesion. Curr. Opin. Cell. Biol. 2011; 23:569-578. [PubMed: 21807492]

47. Collins C, Nelson WJ. Running with neighbors: coordinating cell migration and cell-cell adhesion. Curr. Opin. Cell. Biol. 2015; 36:62-70. [PubMed: 26201843]

48. Yong KL. Granulocyte colony-stimulating factor (G-CSF) increases neutrophil migration across vascular endothelium independent of an effect on adhesion: comparison with granulocytemacrophage colony-stimulating factor (GM-CSF). Br. J. Haematol. 1996; 94:40-47. [PubMed: 8757506]

49. Piscaglia AC, Shupe TD, Oh SH, Gasbarrini A, Petersen BE. Granulocyte-colony stimulating factor promotes liver repair and induces oval cell migration and proliferation in rats. Gastroenterology. 2007; 133:619-631. [PubMed: 17681181]

50. Morris KT, Khan H, Ahmad A, Weston LL, Nofchissey RA, Pinchuk IV, Beswick EJ. G-CSF and G-CSFR are highly expressed in human gastric and colon cancers and promote carcinoma cell proliferation and migration. Br. J. Cancer. 2014; 110:1211-1220. [PubMed: 24448357]

51. Lai CF, Chaudhary L, Fausto A, Halstead LR, Ory DS, Avioli LV, Cheng SL. Erk is essential for growth, differentiation, integrin expression, and cell function in human osteoblastic cells. J. Biol. Chem. 2001; 276:14443-14450. [PubMed: 11278600] 


\section{Highlights}

- The possible contribution of G-CSF to human trophoblast migration was studied.

- $\quad$ G-CSF up-regulated the expression levels of $\beta 1$ integrin.

- $\quad$ G-CSF promoted Swan 71 cell migration by activating PI3K, Erk 1/2 and p38 pathways.

- $\quad$ PI3K behaves as an upstream regulator of Erk 1/2 and p38 MAPK.

- A model showing the signaling pathways involved in G-CSF-induced trophoblast migration is proposed 

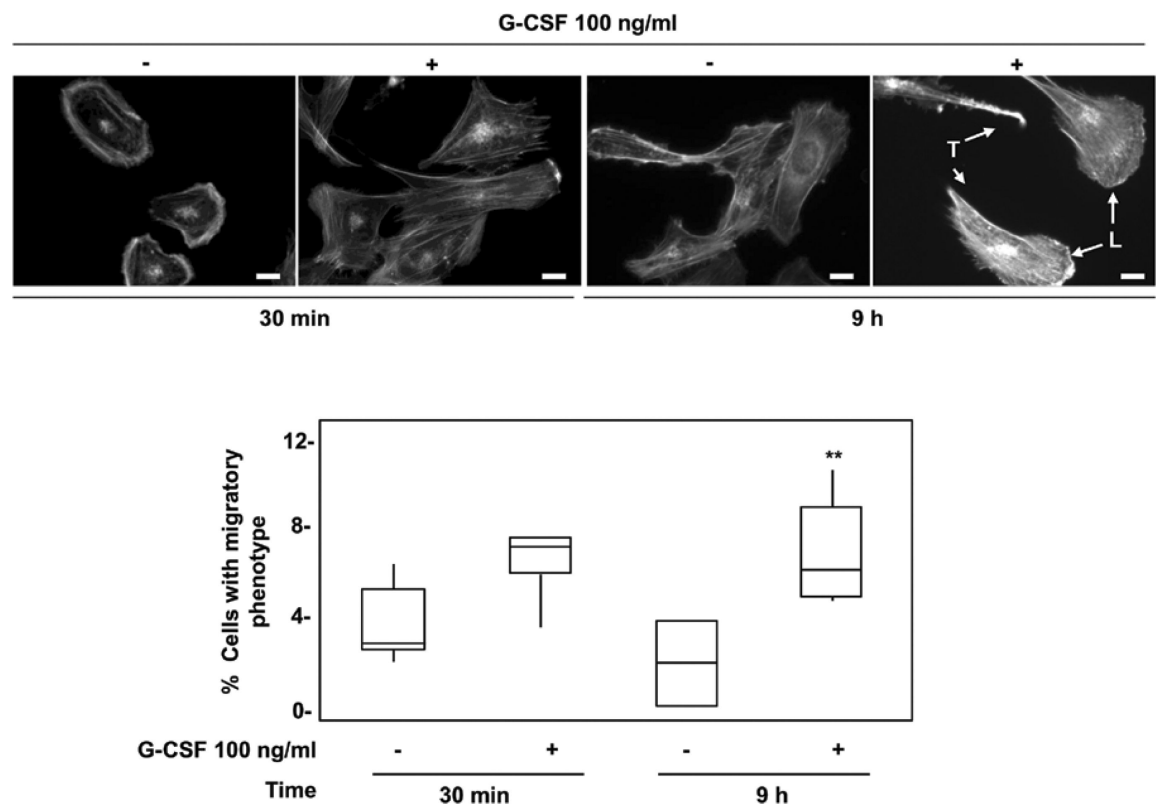

Fig. 1.

Effect of G-CSF on actin cytoskeleton organization in Swan 71 cells. Swan 71 cells grown up on coverslips were incubated $30 \mathrm{~min}$ or $9 \mathrm{~h}$ in the presence or absence of $100 \mathrm{ng} / \mathrm{ml}$ of GCSF. After washing with PBS, cells were fixed with $4 \%$ p-formaldehyde and then incubated with rhodamine-phalloidin. Stained cells were examined with a fluorescence microscope. The percentage of cells with migratory phenotype (presence of lamellipodium, L, and tail, T) from four independent experiments are shown in the lower panel represented in a Box and Whiskers graph. Non-parametric Wilcoxon test, **p<0.01. Magnification 400x, scale bar: $20 \mu \mathrm{m}$. 

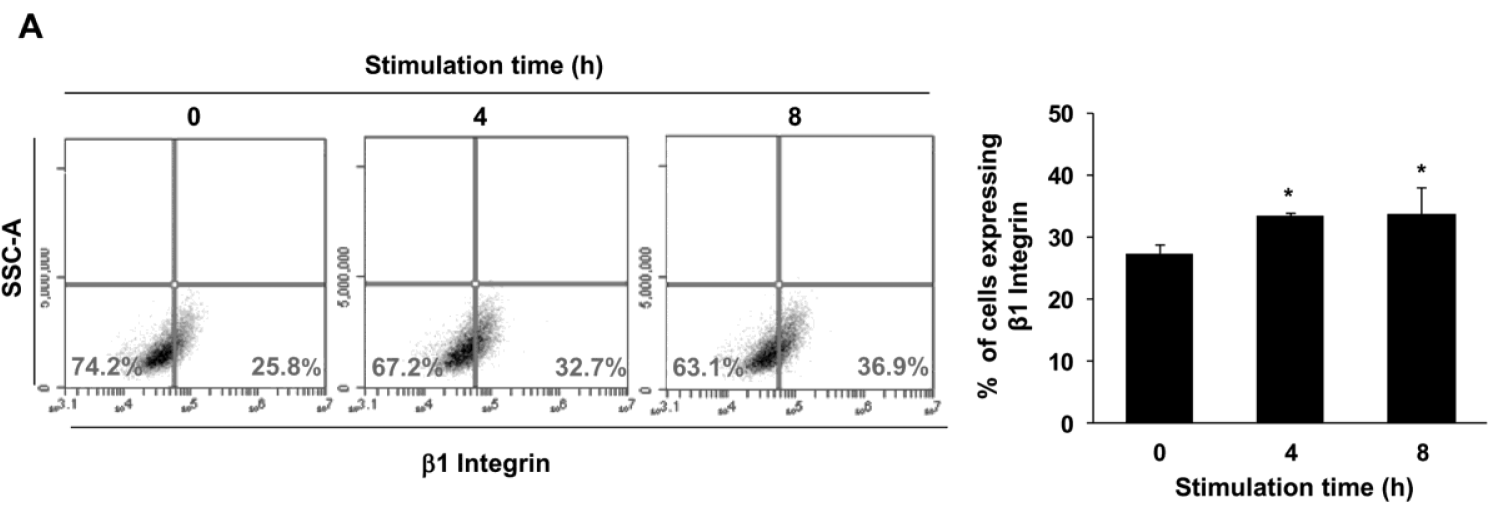

B
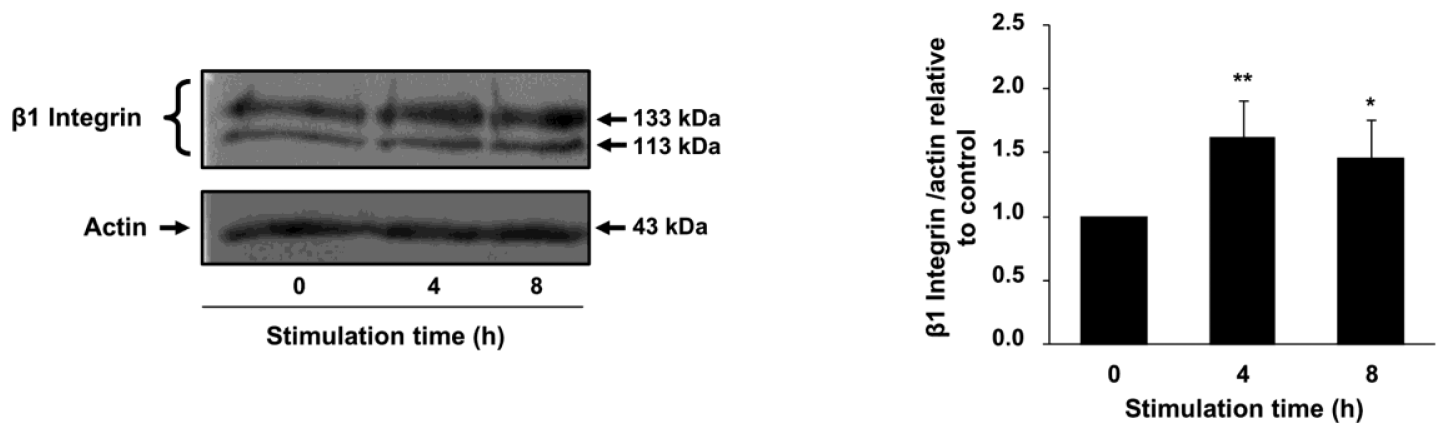

Fig. 2.

$\beta 1$ integrin expression after treatment of Swan 71 cells with G-CSF. Non-confluent monolayers of Swan 71 cells maintained $24 \mathrm{~h}$ in serum-free medium were incubated for 4 and $8 \mathrm{~h}$ in the absence or presence of $100 \mathrm{ng} / \mathrm{ml}$ of G-CSF. (A) After washing with PBS, cells were fixed with $1 \%$ paraformaldehyde and $\beta 1$ integrin expression was analyzed by flow cytometry under the conditions described in Material and methods. Dot plots of one representative experiment are shown. Results are expressed as the media $\pm \mathrm{SE}$ of three independent experiments (right panel). Statistical analyses were performed by one-way ANOVA followed by Bonferroni post-hoc tests. ${ }^{*} \mathrm{p}<0.05$, significantly different from nonstimulated cells. (B) Cell lysates were subjected to SDS-PAGE under the conditions described in Material and methods. Western blot assays were performed with an anti- $\beta 1$ integrin or anti-actin antibody. Results from one representative experiment are shown (left panels). Data quantification was performed by densitometric analysis (right panel). Statistical analyses were performed by one-way ANOVA followed by Bonferroni post-hoc tests. $* \mathrm{p}<0.05, * * \mathrm{p}<0.01,(\mathrm{n}=5)$, significantly different from non-stimulated cells. 
A
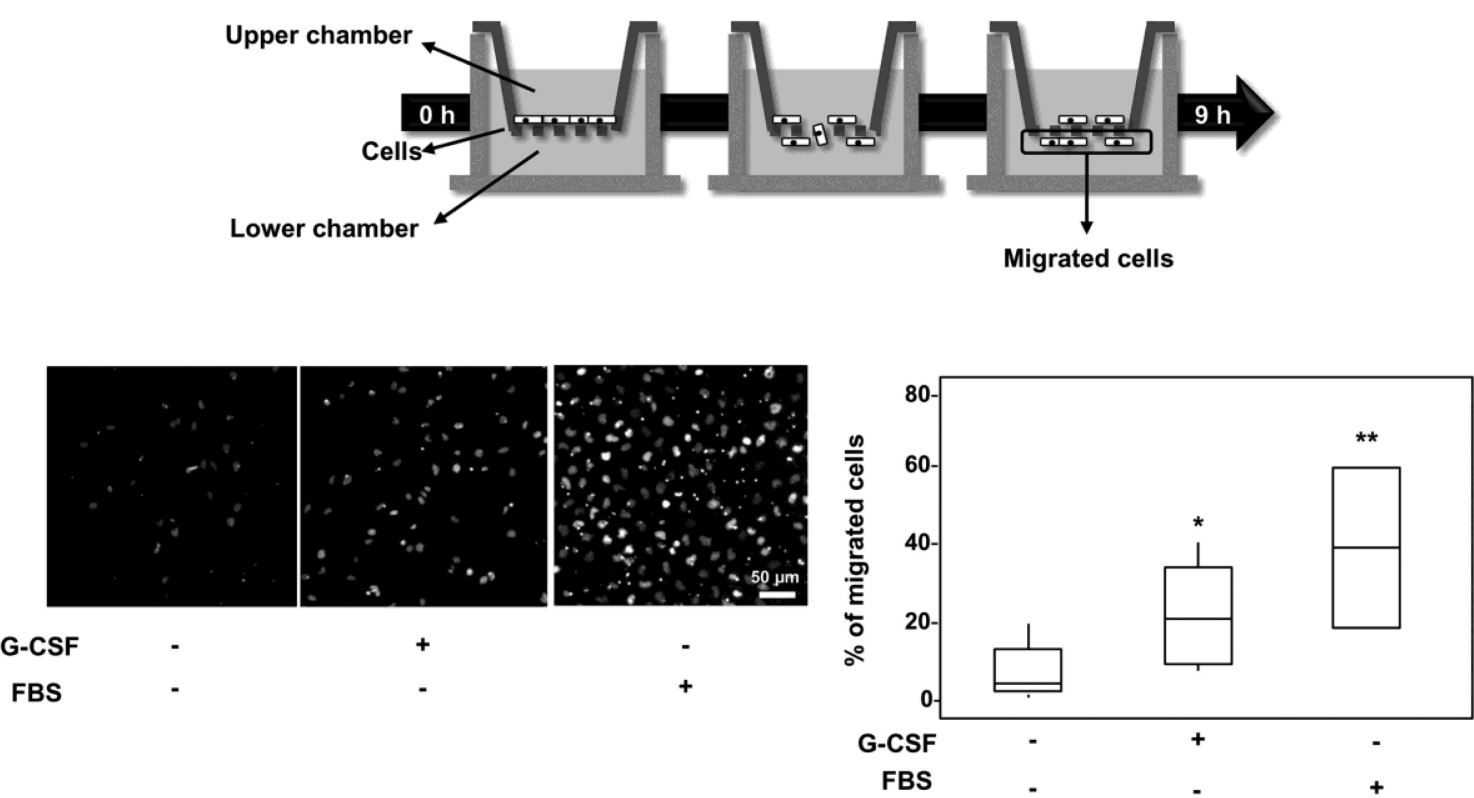

B
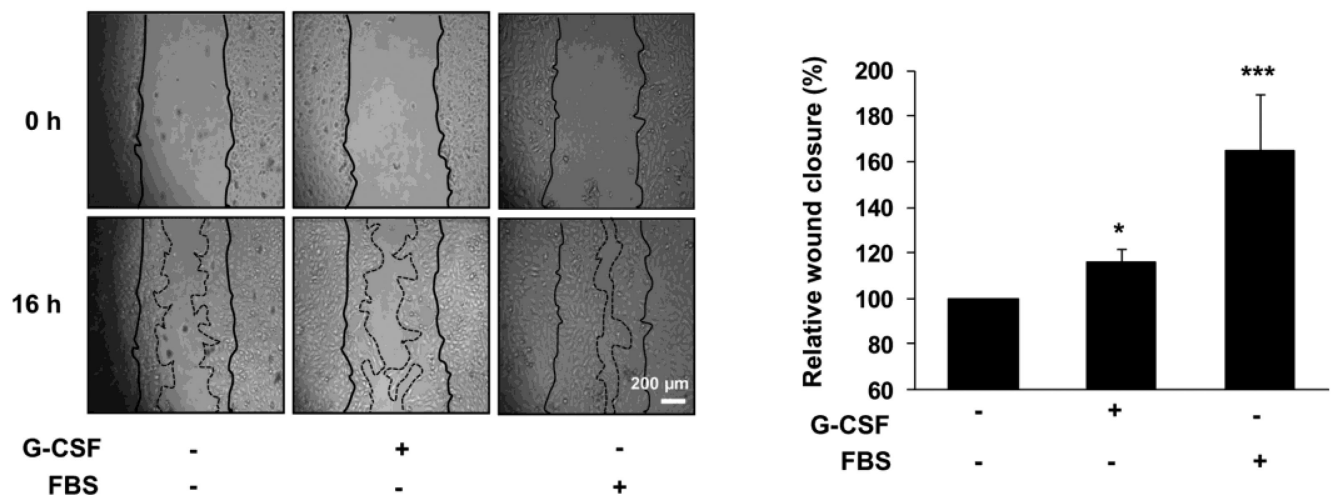

Fig. 3.

G-CSF-induced migration of Swan 71 cells. (A) Swan 71 cells seeded in the upper chamber were allowed to migrate toward the lower chamber containing $100 \mathrm{ng} / \mathrm{ml}$ of G-CSF or $10 \%$ FBS. After swabbing non-migrated cells in the upper chamber, the migrated cells (filter lower face) were stained with DAPI and counted by microscopy. Fields from a representative experiment of DAPI-stained cells are shown (left panel). Scale bar: $50 \mu \mathrm{m}$. Box and Whiskers graph from results of five independent experiments are shown in the right panel. Non-parametric Wilcoxon test, $* \mathrm{p}<0.05, * * \mathrm{p}<0.01$. (B) Monolayers of Swan 71 cells maintained $24 \mathrm{~h}$ in serum-free medium were scratched and incubated with or without 100 $\mathrm{ng} / \mathrm{ml}$ of G-CSF or FBS during $16 \mathrm{~h}$. Pictures were taken at 0 and $16 \mathrm{~h}$ with a camera coupled to a microscopy. Fields from one representative experiment are shown (left panel). The area of the wound was analyzed using Image J. Results are expressed as the media \pm SE of the percentage of wound closure relative to control, $n=9$ (right panel). Statistical analyses were performed by one-way ANOVA followed by Bonferroni post-hoc tests. ${ }^{*} \mathrm{p}<0.05$, $* * * \mathrm{p}<0.001$. 
A

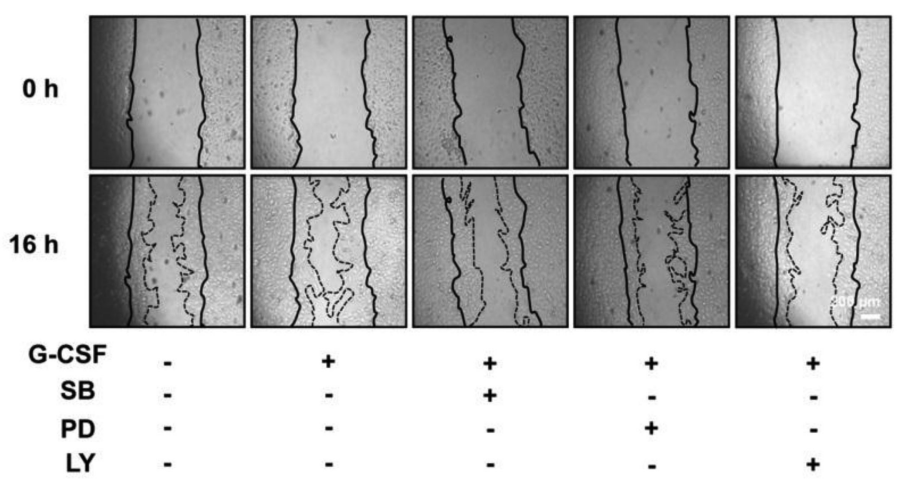

B

h

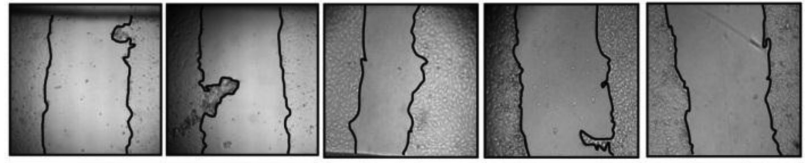

$24 \mathrm{~h}$
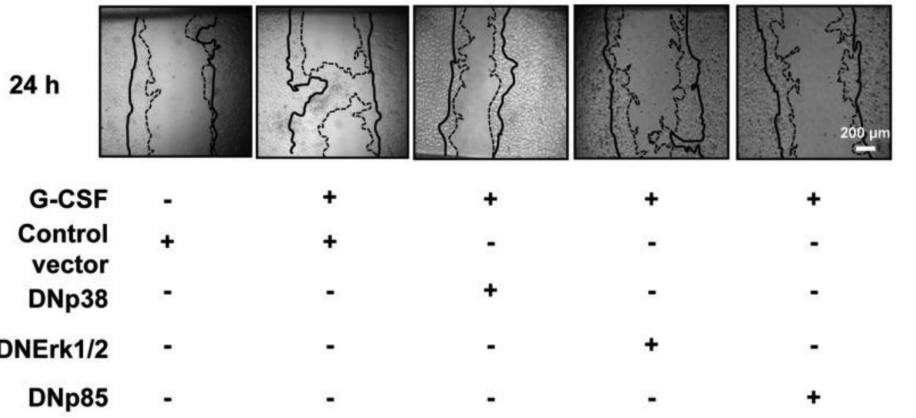

Fig. 4.
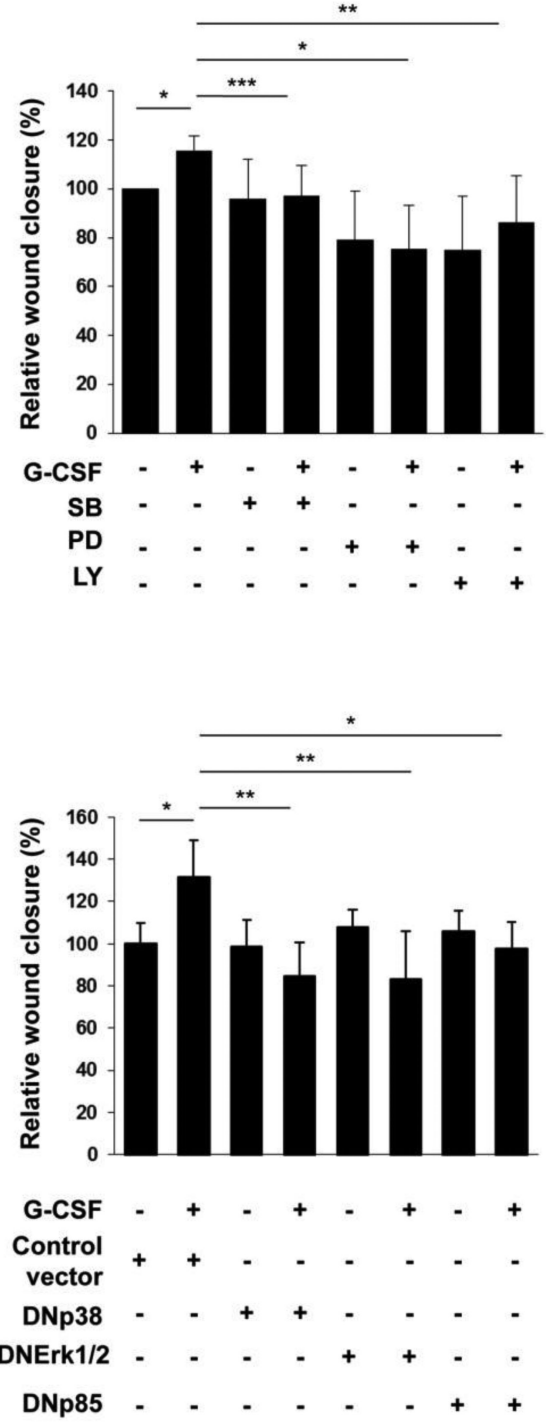

Effect of p38, Erk 1/2 and PI3K pharmacological inhibitors and dominant negatives mutants on G-CSF-induced cell migration. (A) Monolayers of Swan 71 were pre-treated for $1 \mathrm{~h}$ at $37^{\circ} \mathrm{C}$ with or without SB $(2 \mu \mathrm{M})$, PD $(1 \mu \mathrm{M})$ or Ly $(1 \mu \mathrm{M})$. After scratching the monolayers, cells were incubated for $16 \mathrm{~h}$ in serum-free medium containing $100 \mathrm{ng} / \mathrm{ml}$ of G-CSF.

Pictures were taken at 0 and $16 \mathrm{~h}$. Fields from one representative experiment are shown (left panel). The area of the wound was analyzed using Image J. Results are expressed as the media \pm SE of the percentage of wound closure relative to control, $n=6$ (right panel). Statistical analyses were performed by one-way ANOVA followed by Bonferroni post-hoc tests. $* \mathrm{p}<0.05, * * \mathrm{p}<0.01, * * * \mathrm{p}<0.001$. (B) Monolayers of Swan 71 were transiently transfected either with DNp38, DNErk 1/2 and DNp85 constructs or the corresponding control vectors. After scratching the monolayers, cells were incubated for $24 \mathrm{~h}$ in serum-free medium containing $100 \mathrm{ng} / \mathrm{ml}$ of G-CSF. Pictures were taken at 0 and $24 \mathrm{~h}$. Control vector corresponds to results obtained after incubating cells with DNp38 control vector (pcDNA3). Similar results were obtained with DNp85 and DNErk 1/2 control vectors. Fields from one 
representative experiment are shown (left panel). The area of the wound was analyzed using Image J. Results are expressed as the media \pm SE of the percentage of wound closure relative to control, $\mathrm{n}=6$ (right panel). Statistical analyses were performed by one-way ANOVA followed by Bonferroni post-hoc tests. ${ }^{*} \mathrm{p}<0.05,{ }^{* *} \mathrm{p}<0.01$. 
A
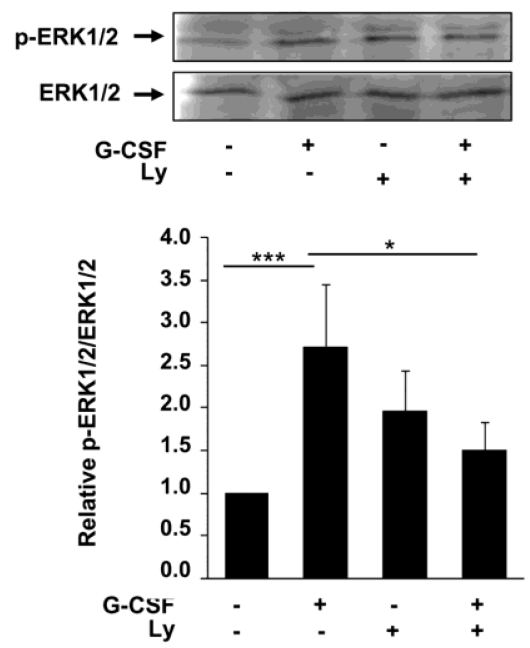

C
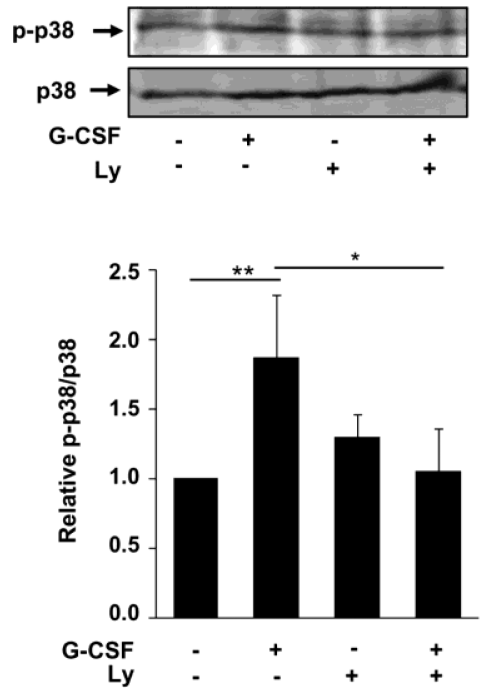

B
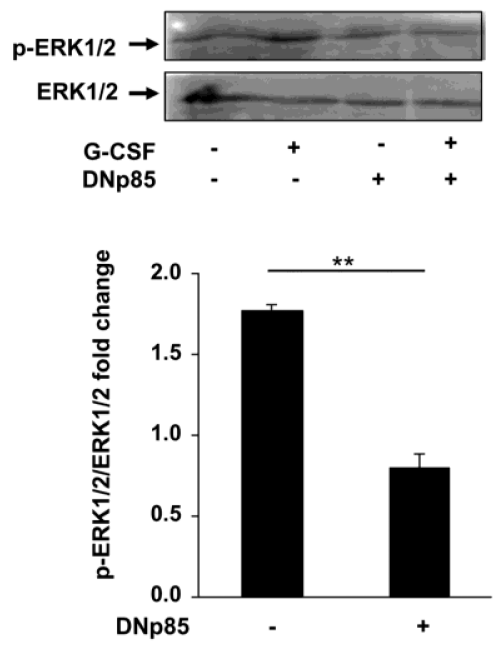

D
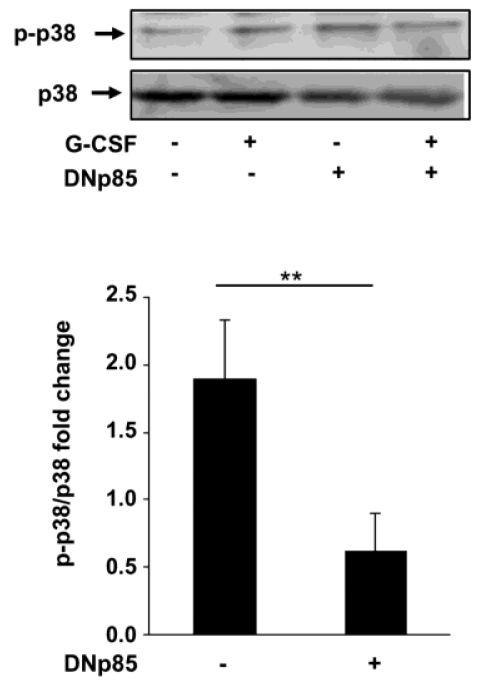

Fig. 5.

Effect of Ly and DNp85 mutant on G-CSF-induced Erk 1/2 and p38 phosphorylation.

Monolayers of Swan 71 cells maintained $24 \mathrm{~h}$ in serum-free medium were pre-treated for $1 \mathrm{~h}$ at $37{ }^{\circ} \mathrm{C}$ with or without $1 \mu \mathrm{M} \mathrm{Ly}$ and then exposed for $15 \mathrm{~min}(\mathrm{~A})$ or $45 \mathrm{~min}(\mathrm{C})$ to 100 $\mathrm{ng} / \mathrm{ml}$ of G-CSF. Alternatively, Swan 71 cells were transfected with the DNp85 construct and then stimulated for $15 \mathrm{~min}$ (B) or $45 \mathrm{~min}$ (D) with $100 \mathrm{ng} / \mathrm{ml}$ of G-CSF. Western blot assays were performed with anti-p-Erk 1/2 and anti-Erk 1/2 (A and B), anti-p-p38 and antip38 (C and D). Results from one representative experiment are shown (top panels). Data quantification was performed by densitometric analysis (lower panels). Statistical analyses were performed by one-way ANOVA followed by Bonferroni post-hoc tests (A and $\mathrm{C}$ ) or Student's t-test (B and D). ${ }^{* * *} \mathrm{p}<0.001, * * \mathrm{p}<0.01,{ }^{*} \mathrm{p}<0.05, \mathrm{n}=3$. 
A
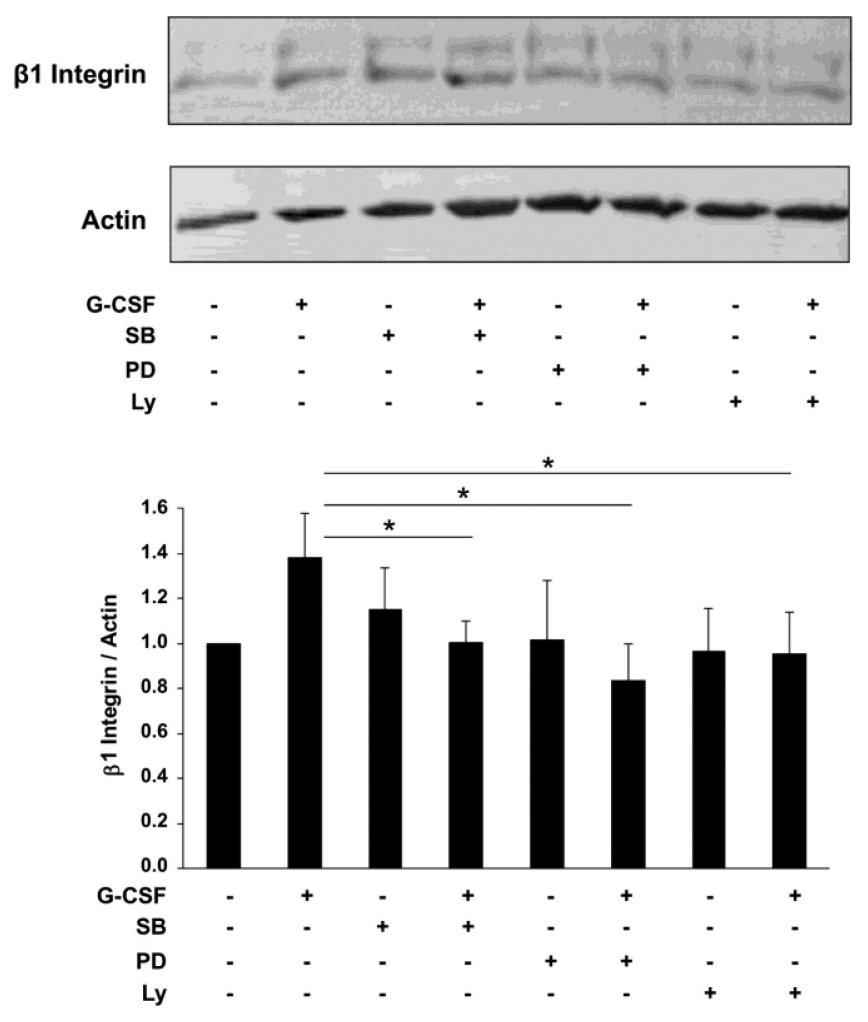

B
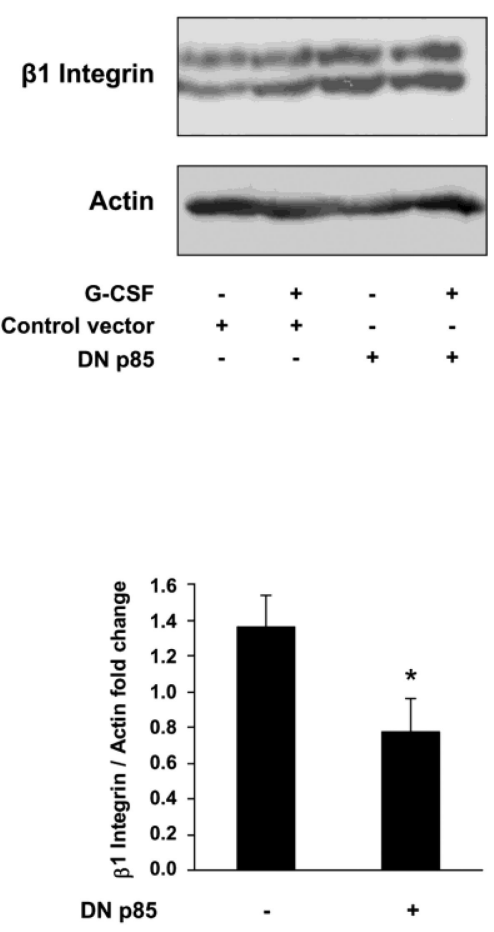

Fig. 6.

Effect of p38, Erk 1/2 and PI3K pharmacological inhibitors and DNp85 mutant on G-CSFinduced $\beta 1$ integrin expression. Monolayers of Swan 71 cells maintained $24 \mathrm{~h}$ in serum-free medium were (A) pre-treated for $1 \mathrm{~h}$ at $37^{\circ} \mathrm{C}$ with or without SB $(2 \mu \mathrm{M})$, PD (1 $\left.\mu \mathrm{M}\right)$ or Ly $(1 \mu \mathrm{M})$ or $(\mathrm{B})$ transfected with DNp85 mutant or the corresponding control vector. Cells were then incubated for $4 \mathrm{~h}$ in the presence or absence of $100 \mathrm{ng} / \mathrm{ml}$ of G-CSF. Western blot assays were performed with anti- $\beta 1$ integrin or anti-actin antibodies. Results from one representative experiment are shown (upper panel). Data quantification was performed by densitometric analysis (lower panel). Statistical analyses were performed by one-way ANOVA followed by Tukey's Multiple Comparison Test (A) or Student's t-test (B). * $\mathrm{p}<0.05, \mathrm{n}=3$. 


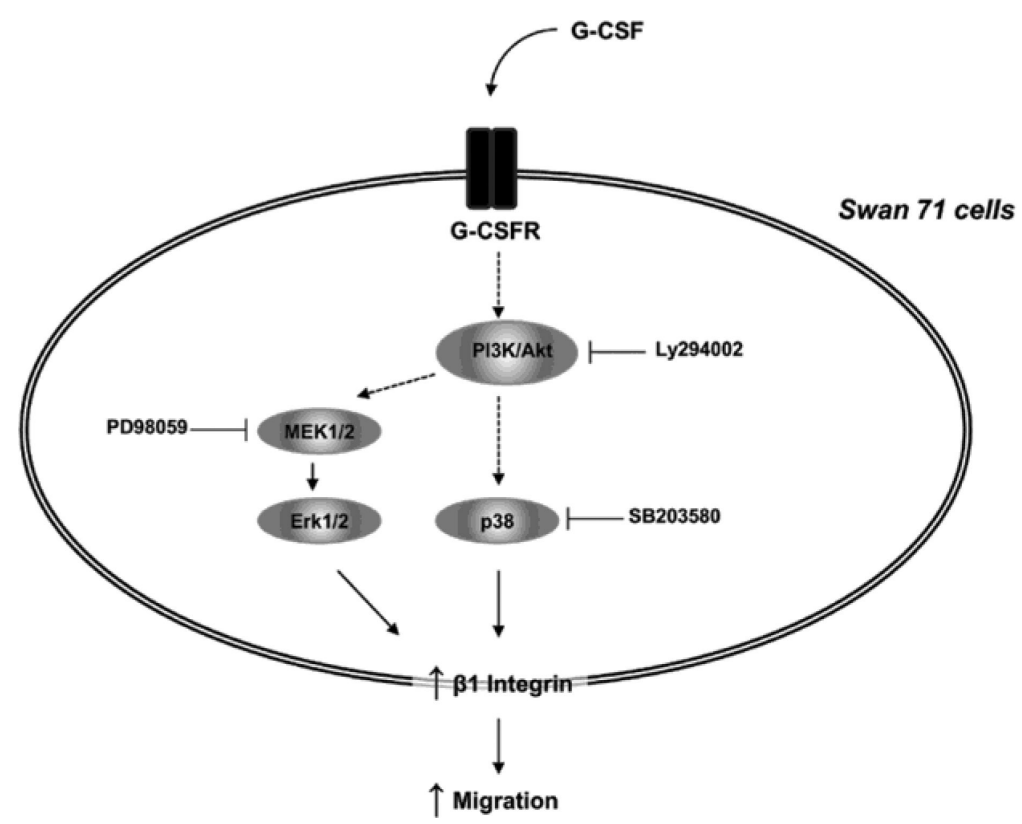

Fig. 7.

Schematic representation of the signaling pathways involved in the migration induced by GCSF in human trophoblast Swan 71 cells. After binding of G-CSF to G-CSF receptor, activation of PI3K/Akt pathway is followed by phosphorylation of p38 and Erk 1/2 MAPKs, leading to an increase of $\beta$ lintegrin expression and cell migration. 